\title{
COMPLEXOS DE NÚCLEOS METAMÓRFICOS: POSSÍVEIS EXEMPLOS NO PRECAMBRIANO BRASILEIRO
}

G.R.Sadowski ${ }^{1}$

Os Complexos de Núcleo Metamórfico foram definidos formalmente na América do Norte como "Metamorphic Core Complexes" onde, somente na região das Montanhas Rochosas, afloram em cerca de 25 locais, desde o Canadá até o norte do México

Os Complexos se caracterizam por possuírem um núcleo geralmente plutonometamórfico, sobre o qual foi impressa uma foliação milonítica de baixo ângulo, geralmente gnáissica e portadora de uma nítida lineação. Os terrenos de cobertura ou simplesmente, coberturas, costumam ser de grau metamórfico bem mais baixo, podendo ser anquimetamórficos e, circundam o núcleo, passando por uma rápida transição metamórfica. Entre a cobertura e o núcleo observam-se duas zonas intermediárias, a carapaça e a zona de descolamento. A carapaça consiste de camadas metamorfizadas em fácies anfibolito ou xistoverde envolve concordantemente o núcleo (geralmente gnáissico), estando amalgamada ao mesmo com suas rochas tectonicamente emplastradas por sobre os gnaisses e apresentando uma intensa deformação pervasiva em diferentes escalas. Por outro lado, a passagem da cobertura para a carapaça ou, na ausência dessa última, da cobertura para o núcleo, se evidencia através de um nítido contraste de estilo estrutural dando-se por falhamento e cisalhamento de baixo ângulo. Estes caracterizam uma zona de descolamento tectônico. Cabe salientar que a zona de descolamento separa pacotes de estilo estrutural diverso contrastando muito a independência de estilo da cobertura em relação ao de núcleo (Fig. 1).

Os complexos de núcleo metamórfico ocorrem freqüentemente nas zonas axiais dos orógenos e, apesar de freqüentemente estarem relacionadas a feições de distensão, encontram-se aparentemente no interior do arco magmático e não por trás do mesmo. Sua

\footnotetext{
${ }_{1}$ Departamento de Geologia Geral, Instituto de Geociências/USP, São Paulo.
} 
origem, modelagem e caráter aparentemente distensivo ainda continuam enigmáticos.

No vasto território precambriano brasileiro, o autor permite-se apenas sugerir que algumas destas feições possam ser identificadas dentro da Faixa Ribeira e no Cinturão Tocantins-Araguaia, merecendo portanto uma análise sob este enfoque estrutural. Seriam o domo ou "anticlinório" de Adrianópolis (Serra do Cadeado) ou Anticlinal da Serra da Boa Vista no Estado do Paraná e dos domos ou braquidobras de Colméia, Lontra e Xambioá na região do Araguaia.

O autor teve a oportunidade de estudar com certo detalhe a estrutura da Serra do Cadeado e de Colméia. A primeira apresenta um núcleo de gnaisses miloníticos porfiróides escuros intercamadados tectonicamente com granada-biotita-quartzo-xistos, com uma intensa lineação subhorizontal de estiramento impressa nos porfiróides de feldspato (ca. de 6:2:1) e nos cristais de granada. Sua atitude oscila ao redor de N40W a N60E subhorizontal (talvez associada a falhamento de baixo ângulo com transportes para NW). A carapaça parece ser constituída por cerca de $150 \mathrm{~m}$ de metassedimentos e vulcânicas na forma de metagrauvacas, quartzitos e anfibolitos intensamente folheados e boudinados com a foliação cataclástica preenchida por biotitas. Por cima desta carapaça viria a cobertura constituída pelo Grupo Perau, com dois espessos pacotes de quartzito (metacherts?) na base, seguidos de para e ortoanfibolitos, xistos e calcossilicáticas, indicando forte transposição tectônica. A seguir, mais a W, passa-se aos grafita e sericita-filitos, usualmente atribuídos ao Açungui. Sem dúvida, admitimos na presente fase de conhecimento, interpretações alternativas, incluindo nappes ou efeito de embasamento.

A estrutura de Colméia, descrita por diferentes autores, também mostra ser bastante sugestiva. No seu interior encontramos gnaisses mais antigos com foliação de baixo ângulo intrudidos por granitóides. Ocorre uma rápida transição metamórfica de xistos na fácies anfibolito a filitos e calcofilitos de baixo grau. Também neste caso pode-se pensar em uma relação associada a intensa tectônica horizontal. Xambioá e Lontra parecem seguir padröes similares, notando-se diferenças menores. 


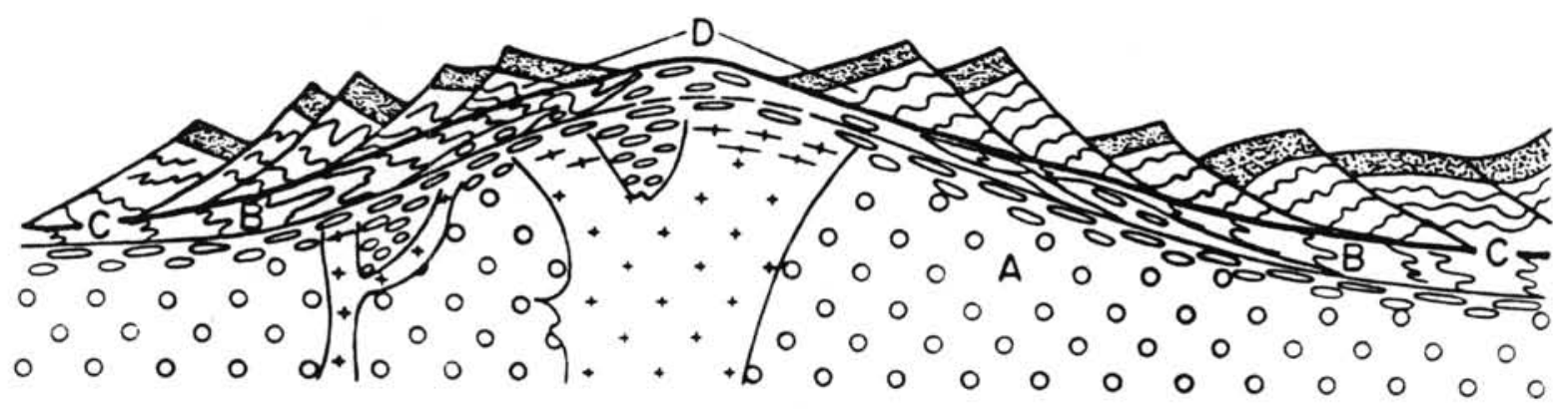

Figura 1 - Estrutura ideal de um complexo de núcleo metamórfico. A - núcleo gnáissico-granitóide com envoltória intensamente deformada; B - carapaça; C - zona de descolamento; D - cobertura. 